\title{
Supply of additional working fluid to the flow part of the NK-8 gas turbine engine
}

\author{
George Marin ${ }^{1,2}$, Dmitrii Mendeleev ${ }^{1,2, *}$, Boris Osipov $^{1}$, and Azat Akhmetshin ${ }^{1}$ \\ ${ }^{1}$ Kazan State Power Engineering University, 420034, Krasnoselskaya St., 51, Kazan, Russian Federation; \\ ${ }^{2}$ JSC "Tatenergo" branch "Kazan CHP-2", 420036, Tatsevskaya St., 11, Kazan, Russian Federation
}

\begin{abstract}
Modern energy development strategies of advanced countries are based on the construction of gas turbine units which is associated with sufficiently high values of thermal efficiency and a relatively short term for putting them into operation. In this paper, the NK-8 engine is considered. It is modernized with a mixing chamber and a power turbine for the purpose of its ground application. A study was conducted of the injection of an additional working fluid into the flow part of a dual-circuit gas turbine engine. Steam is used as an injectable substance. For research a mathematical model was created in the AS «GRET» software package. The studies were carried out under constant load, the maximum load during injection was determined. An additional worker can be supplied with summer power limitations when it is necessary to increase the power of a gas turbine installation. Studies have shown that the maximum power that can be obtained by supplying steam to the flow part is $32.2 \mathrm{MW}$.
\end{abstract}

\section{Introduction}

In any country, energy is a basic sector of the economy. Energy provides the prerequisites for the application of new technologies and along with other factors provides a modern standard of living for the population. Currently, the development of energy is based on gas turbine technologies. [1-2]

In order to ensure maximum thermal efficiency the initial parameters of the gas turbine (temperature and the degree of pressure increase in the compressor) are continuously increasing. At the same time, other opportunities are being used to increase the efficiency and specific power of the plants (intermediate cooling of the air in the compressor, reheating of the working fluid of the gas turbine in front of the power turbine)

\section{Gas turbine description and research model}

In a gas turbine engine of a simple design, an increase in the useful work of the engine can be achieved by reducing the cost of compressor drive. Reducing the work on air compression can be achieved by cooling the air in the compressor path or by supplying an additional working fluid. The working fluid may be water or steam. There is always excess steam of different temperatures and pressures at the thermal power station, therefore, steam was chosen for research as the injected substance. [3-5]

The engine NK-8 was selected as the engine under study. The main characteristics of the gas turbine installation are presented in table 1. A longitudinal section of the engine is shown in Figure 1.

The engine includes:

1. Two-stage eleven-stage compressor;

2. Multi-nozzle combustion chamber;

3. Two-stage three-stage axial gas turbine.

Table 1. Technical characteristics of a GTU (NK-8).

\begin{tabular}{|c|c|c|c|}
\hline No & Characteristic & $\begin{array}{c}\text { Meas. } \\
\text { unit }\end{array}$ & Value \\
\hline 1 & Air flow & $\mathrm{kg} / \mathrm{s}$ & 289 \\
\hline 2 & Compression ratio & & 12.93 \\
\hline 3 & $\begin{array}{c}\text { Temperature in the } \\
\text { combustion chamber }\end{array}$ & $\mathrm{K}$ & 1179 \\
\hline 4 & $\begin{array}{c}\text { Expansion ratio in high } \\
\text { pressure turbine }\end{array}$ & 2.278 \\
\hline 5 & $\begin{array}{c}\text { Expansion ratio in low } \\
\text { pressure turbine }\end{array}$ & & 2.64 \\
\hline
\end{tabular}

The engine consists of the following main components - a low-pressure compressor, a highpressure compressor, an annular combustion chamber, a high-pressure turbine and a low-pressure turbine. All of these units can be used in completing installations for various power values output to the drive shaft. [6-9]

The low-pressure compressor (LPC) is five-stage. It consists of a rotor and a stator. The rotating part of the LPC - the rotor has five working rings (according to the number of steps). The first two stages fan operated on both circuits. The remaining three steps compress the air in the internal circuit. The fixed part of the LPC - stator has guide vanes. There is an input guide vane (IGV) with guide vanes in front of the stator, which serves to direct airflow to the vanes of the first stage of the compressor.

\footnotetext{
* Corresponding author: dylankn@ya.ru
} 


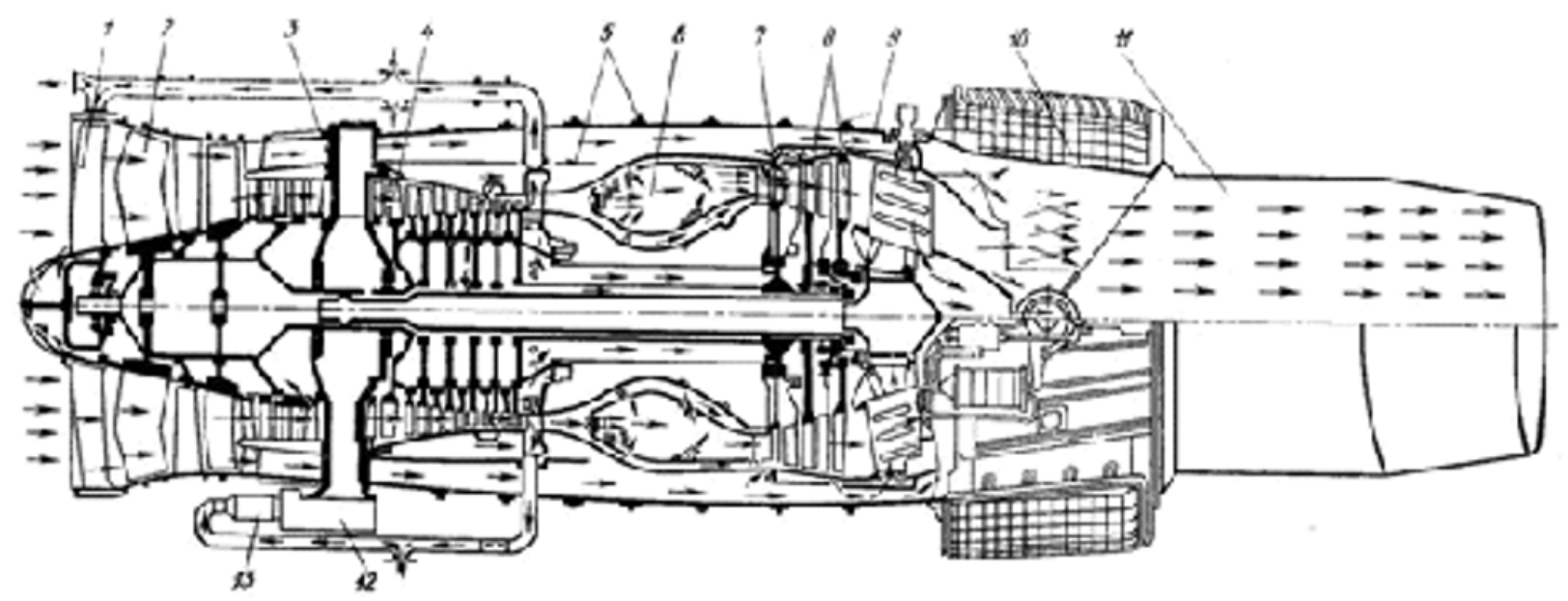

Fig. 1. A longitudinal section of the engine ( 1 - an input guide vane; 2 - a low pressure compressor; 3 - a middle support; 4 - a high pressure compressor; 5 - a shell; 6 - a combustion chamber; 7 - a high pressure pipe; 8 - a low pressure turbine; 9 - a spacer; 10 - a reversible device; 11 - a jet nozzle; 12 - a box of engine units; 13 - a box of aircraft units).

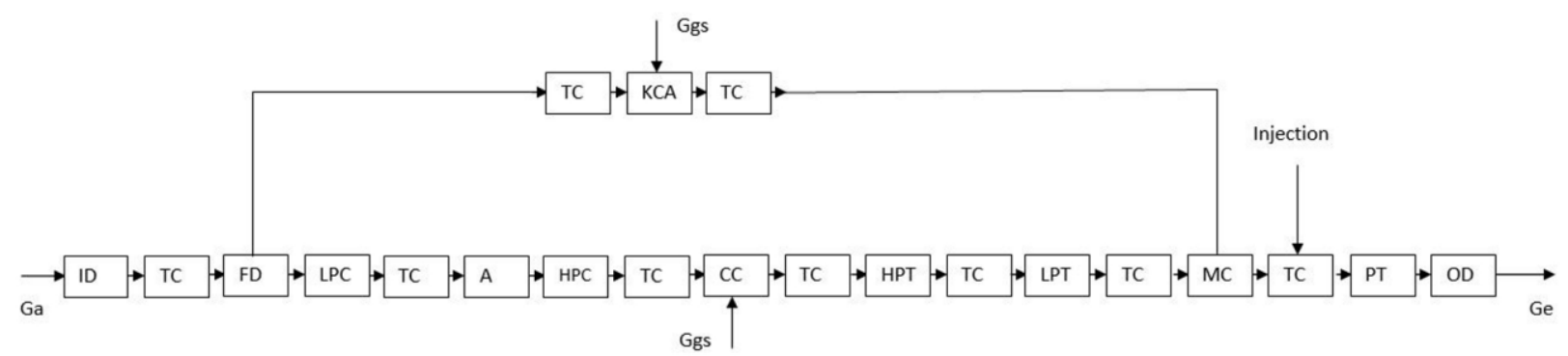

Fig. 2. The functional diagram of the mathematical model (ID - an input device; TC - a transition channel; FD - a flow distributor; LPC - a low pressure compressor; CC - a combustion chamber; A - an aggregates; HPC - a high pressure compressor; HPT - a high pressure turbine; LPT - a low pressure turbine; MC - a mixing chamber; PT - a power turbine; OD an output device; CCWAB - a combustion chamber with afterburner device; Ga - an air consumption; Ggs - a gas supply; Ge an exhaust gas flow).

The high-pressure compressor (HPC) is six-speed. It consists of a rotor and a stator. The rotor has six impellers as well as a front shaft. The stator has guide vanes. There is a guide vane with adjustable blades at the front of the stator.

The high-pressure turbine (HPT) is lightly loaded and operates at low temperatures, therefore, there are two options for the blades of nozzle devices - without cooling and with cooling. (The cooling option is used for higher temperatures).

The low-pressure turbine (LPT) is an axial singlestage turbine designed for high efficiency parameters.

Related design features of the engine include the presence of a second circuit, which can replace the external thermal insulation of the engine. [10-11]

For ground-based applications, this gas turbine engine has been upgraded with a free power turbine, a afterburner in the secondary circuit and a mixing chamber. The mathematical model of the engine was created in the «GRET» software package. The functional diagram is shown in Figure 2.

\section{Results and Discussion}

The afterburning device is necessary to prevent moisture condensation in the engine flow passage. When injecting steam into the flowing part, it is necessary to take into account the fact that the temperature of the exhaust gases after the gas turbine engine must not be lower than 460 $\mathrm{K}$ in order to avoid moisture condensation. For this, it is necessary to increase the temperature in the afterburner (located in the second circuit) until the temperature is reached after mixing the gas flows of the first and second circuit. [12-14]

Steam injection is performed in front of the power turbine at a pressure of $0.3 \mathrm{MPa}$ and a temperature of $560 \mathrm{~K}$. With these parameters, no condensation occurs in the flow part.

Figure 3 shows the dependence of the change in efficiency and the total hourly fuel consumption depending on the test mode. The parameters of the modes (turbine power and injection flow rate are shown in table 2). The maximum flow rate of the injected substance is limited to $27 \mathrm{~kg} / \mathrm{s}$ - this is due not only to the cross section of the flowing part of the gas engine but also to the fact that with a higher value airflow will decrease. [15-17] 


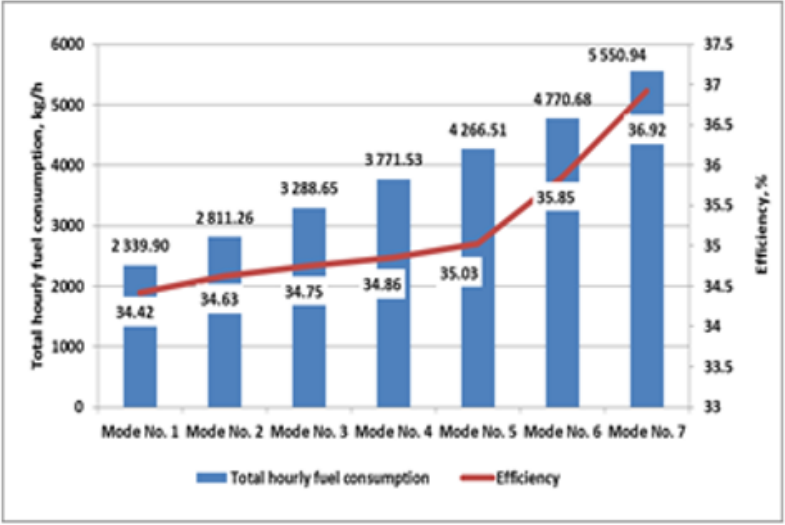

Fig. 3. Change in efficiency depending on injection flow.

Table 2. The parameters of the modes.

\begin{tabular}{|c|c|c|c|c|c|c|c|}
\hline $\begin{array}{c}\text { Mode } \\
\text { number }\end{array}$ & 1 & 2 & 3 & 4 & 5 & 6 & 7 \\
\hline $\begin{array}{c}\text { Turbine } \\
\text { Power, } \\
\text { MW }\end{array}$ & 12 & 14 & 16 & 18 & 20 & 22 & 25 \\
\hline $\begin{array}{c}\text { Injection } \\
\text { rate, } \\
\mathrm{kg} / \mathrm{s}\end{array}$ & 0 & 8 & 10 & 15 & 20 & 25 & 27 \\
\hline
\end{tabular}

Figure 4 shows the change in enthalpy and useful work depending on the flow rate of the injected substance.

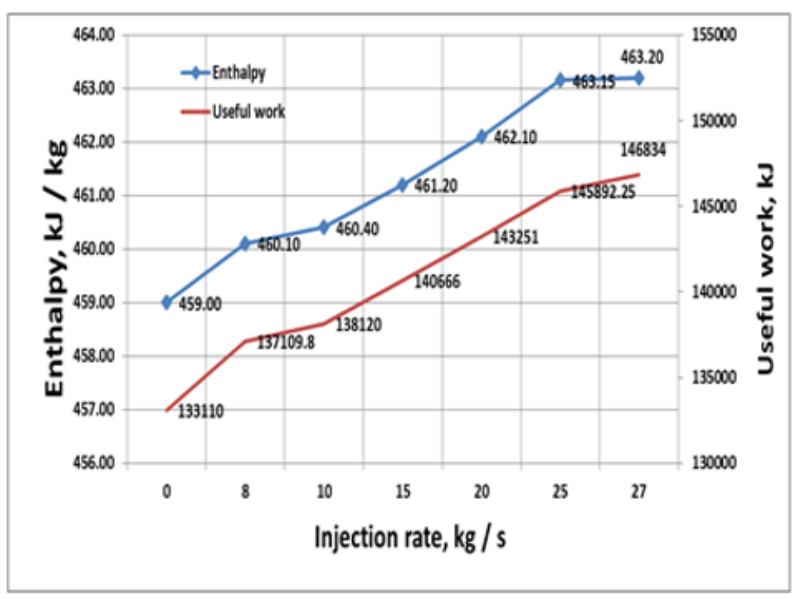

Fig. 4. The change in enthalpy and useful work depending on the flow rate of the injected substance.

During the research, it was assumed that when supplying an additional working fluid, the bypass ratio of the engine may change. Because the gas turbine should work not only in the basic mode at a load of 25 MW but also in other modes a study was conducted to find the optimal value of the bypass ratio.

Because all generating equipment operates in the wholesale electricity market, the operation of a gas turbine is possible not only at a full capacity of $25 \mathrm{MW}$ but also in variable modes. [18-23]

Figures 5-7 show a graphs of changes in the main energy characteristics of the engine. Loads from $12 \mathrm{MW}$ to $25 \mathrm{MW}$ are considered.

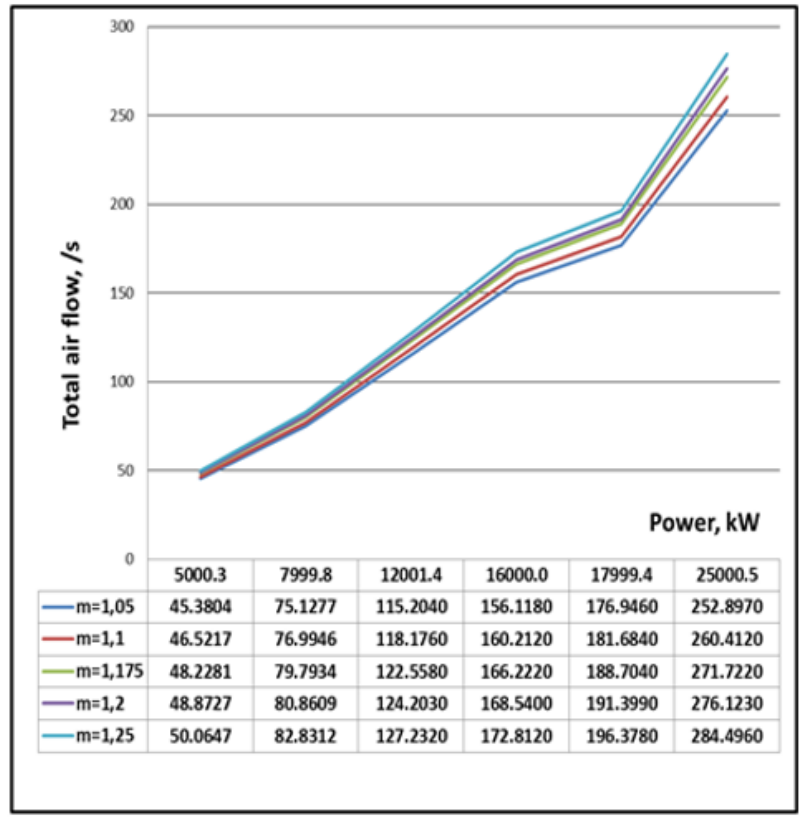

Fig. 5. Change in air flow depending on the degree of bypass and power of gas turbines.

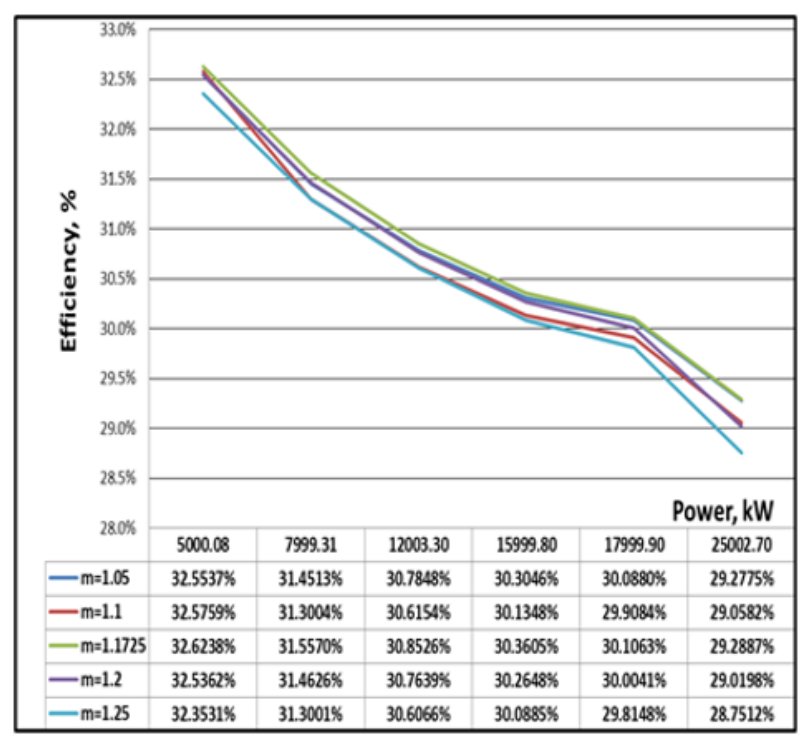

Fig. 6. Change in turbine efficiency depending on the degree of dual-circuit and power of a gas turbine. 


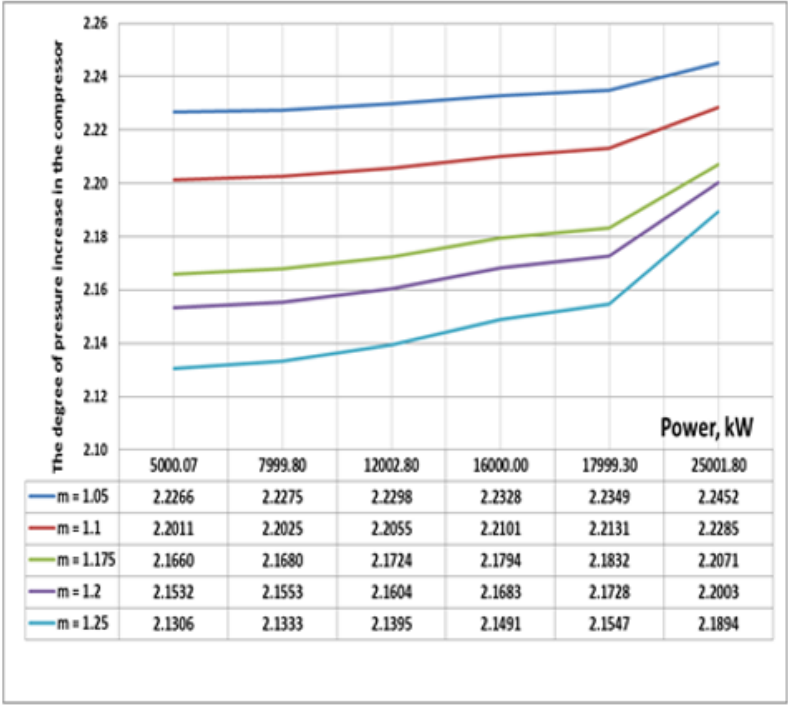

Fig. 7. Change in the degree of increase in pressure in the compressor depending on the degree of double-circuit and power of gas turbine.

\section{Conclusion}

This article studies the operating modes of the NK-8 gas turbine engine in double-circuit design, upgraded by a power turbine, afterburner and mixing chamber.

Steam injection in front of the power turbine leads to a steady increase in power and effective efficiency. It is necessary to exclude the possible condensation of moisture in the flow part when steam is injected.

The bypass ratio also affects the turbine performance, the optimal value is 1.175 .

\section{References}

[1] O.O. Badran, Appl. Energy (1999)

[2] M. Basha, S.M. Shaahid, L. Al-Hadhrami, Energy Procedia (2012)

[3] G.E. Marin, B.M. Osipov, D.I. Mendeleev, E3S Web Conf. 124 (2019)

[4] D.I. Mendeleev, G.E. Maryin, A.R. Akhmetshin, IOP Conf. Ser. Mater. Sci. Eng. (2019)

[5] D.I. Mendeleev, Y.Y. Galitskii, G.E. Marin, A.R. Akhmetshin, E3S Web Conf. 124 (2019)

[6] E. Bocci, M. Sisinni, M. Moneti, L. Vecchione, A. Di Carlo, M. Villarini, Energy Procedia (2014)

[7] T.A. Clifford, S. Cruz-Manzo, Y. Zhang, V. Panov, A. Latimer, Proc. IECON 2017 - 43rd Annu. Conf. IEEE Ind. Electron. Soc. (2017)

[8] L. Esclapez, P.C. Ma, E. Mayhew, R. Xu, S. Stouffer, T. Lee, H. Wang, M. Ihme, Combust. Flame (2017)

[9] L. Esclapez, P.C. Ma, E. Mayhew, R. Xu, S. Stouffer, T. Lee, H. Wang, M. Ihme, Combust. Flame (2017)

[10] E. Gracheva, A. Alimova, Proc. - 2019 Int. Russ. Autom. Conf. RusAutoCon (2019)
[11] E. Gracheva, A. Alimova, Proc. - 2019 Int. Ural Conf. Electr. Power Eng. Ural (2019)

[12] M. Henke, J. Kallo, K.A. Friedrich, W.G. Bessler, Fuel Cells (2011)

[13] J. Hou, B.J. Wicks, R.A. Antoniou, Eng. Fail. Anal. (2002)

[14] J. Kotowicz, M. Job, M. Brzeczek, Energy (2015)

[15] M.C. Lee, S. Bin Seo, J.H. Chung, S.M. Kim, Y.J. Joo, D.H. Ahn, Fuel (2010)

[16] A.H. Lefebvre, J.H. Whitelaw, Int. J. Heat Fluid Flow (1984)

[17] K. Liu, S. Sadasivuni, N. Parsania, Fuel (2019)

[18] W. E. Bill Forsthoffer, Forsthoffer's Rotating Equip. Handbooks (2005)

[19] M.M. Rahman, T.K. Ibrahim, A.N. Abdalla, Int. J. Phys. Sci. (2011)

[20] D. Rochelle, H. Najafi, Renew. Sustain. Energy Rev. (2019)

[21] P. Weiland, Appl. Microbiol. Biotechnol. (2010)

[22] K. Weston, Energy Convers (2000)

[23] Y.G. Li, P. Nilkitsaranont, Appl. Energy (2009) 